\title{
Parathyroid Chief Cell Hyperplasia
}

National Cancer Institute

\section{Source}

National Cancer Institute. Parathyroid Chief Cell Hyperplasia. NCI Thesaurus. Code C6032.

A hyperplasia of the chief cells of the parathyroid gland. 